\title{
Liquid/air partition coefficients of four terpenes
}

\author{
A Falk, E Gullstrand, A Löf, E Wigaeus-Hjelm
}

\begin{abstract}
The liquid/air partition coefficients of four common terpenes, $\alpha$-pinene, $\beta$-pinene, 3 carene, and limonene, have been determined in vitro using head space technique. The liquids used were water, human blood, and olive oil. $\alpha$-Pinene, $\beta$-pinene, and 3-carene were practically insoluble in water and limonene was slightly soluble; all were readily dissolved in olive oil. The oil/air partition coefficients ranged from 2900 to 5700 in the order $\alpha$-pinene, $\beta$-pinene, 3-carene, and limonene. The blood/ air partition coefficients ranged from 15 to 42 in the same order as for oil/air.
\end{abstract}

Terpenes occur naturally in pine trees and certain bushes. The major components are the monoterpenes $\alpha$-pinene and $\beta$-pinene. 3-Carene and limonene are common terpenes but vary in quantity. The proportion of separate terpenes varies with season, species, and locality. ${ }^{1}$ The liberation of volatile terpenes during sawing or processing of fresh wood is a source of exposure for workers in sawmills. ${ }^{23}$ Terpenes are also present as a byproduct in sulphate extraction processes and as solvents.

Respiratory and percutaneous uptake of terpenes has been observed in $\operatorname{man}^{45}$ but no quantitative study of absorption appears to have been conducted. In the rat terpenes accumulate in peripheral fat, kidneys, and brain. ${ }^{67}$ Slow renal elimination was observed in an acutely poisoned patient. ${ }^{8}$ Terpenes irritate the skin and mucous membranes ${ }^{14}$ and prolonged exposure may result in allergic contact dermatitis ${ }^{910}$ or chronic lung function impairment after several years exposure. ${ }^{2311}$

Absorption, distribution, and excretion rates depend largely on the tissue solubility and tissue solubility on the partition coefficients between blood/air and tissue/blood. The partition coefficients $(\lambda)$ are therefore important for the prediction of the toxicokinetics and have been established for many solvents, ${ }^{12-15}$ though not for terpenes.

The aim of the present study was to determine the

Division of Work and Environmental Physiology, National Institute of Occupational Health, Solna, Sweden

A Falk, E Gullstrand, A Löf, E Wigaeus-Hjelm in vitro blood/air, oil/air, and water/air partition coefficients of four common terpenes: $\alpha$-pinene, $\beta$ pinene, 3-carene, and limonene.

\section{Materials and methods \\ CHEMICALS}

The chemicals used were sodium chloride (analytical grade, Merck), olive oil (purum, Kebo Lab AB), $\alpha$ pinene (98\%, Aldrich), $\alpha$-pinene (98\%, Aldrich), 3carene $(95 \%$, Aldrich), and limonene $(99 \%$, Fluka Chemie AG). All chemicals were used without further purification.

\section{SAMPLE PREPARATION}

Blood was collected from the brachial vein of ten healthy volunteers (five men and five women) in heparinised $10 \mathrm{ml}$ Vacutainer tubes (Beckton Dickinson, Paramus, $\mathrm{NJ}$ ) and were pooled immediately before the experiment. Aliquots of $0.5 \mathrm{ml}$ olive oil, $2 \mathrm{ml}$ water (containing $0.3 \mathrm{M}$ sodium chloride), or $2 \mathrm{ml}$ pooled fresh human blood were added to a head space vial $(22.4 \mathrm{ml}, \mathrm{SD}=0.2)$. A reference vial was filled with glass beads to a volume corresponding to the sample volume $(0.5$ and $2 \mathrm{ml}$, respectively) and treated exactly the same way as the sample; this was done to reduce the difference in pressure which could affect the partition coefficient.

To obtain the desired concentrations (0.84$354 \mu \mathrm{M}$ in oil and 0.21-89 $\mu \mathrm{M}$ in blood and water) 3 , 30 , or $250 \mu \mathrm{l}$ of each terpene was added to a thermostated $\left(37^{\circ} \mathrm{C}\right)$ air chamber of 4.4451 volume. After 20 minutes equilibration $\left(37^{\circ} \mathrm{C}\right)$ a sample of $0 \cdot 1,0 \cdot 25$, or $0.5 \mathrm{ml}$ was taken out with a gas tight syringe and added into a head space vial. Before the standards were made, the head space vials were thermostated $\left(37^{\circ} \mathrm{C}\right)$ and capped with Teflon lined rubber stoppers. An air volume (corresponding to the sampling volume later added to each vial) was taken from each vial with a gas tight syringe. Blanks of blood, olive oil, and water were made without added terpenes. Double samples were made, in each liquid, for all the concentrations.

\section{GAS CHROMATOGRAPHIC ANALYSIS}

The terpenes in the gas phase of the headspace vials were determined by gas chromatography (Perkin Elmer 8700) using a head space autosampler (Perkin Elmer HS-101) and a flame ionisation detection. A polar, wide bore capillary glass column (Supelcowax 10 , Supelco inc $30 \mathrm{~m}, 0.75 \mathrm{~mm}$ inner diameter, 
$1.0 \mu \mathrm{m}$ bonded phase) was used. The temperatures were as follows: head space autosampler $37^{\circ} \mathrm{C}$, needle $100^{\circ} \mathrm{C}$, transfer line $100^{\circ} \mathrm{C}$, injector $260^{\circ} \mathrm{C}$, initial column temperature $80^{\circ} \mathrm{C}$. The column temperature was increased with $5^{\circ} \mathrm{C} / \mathrm{min}$ to $115^{\circ} \mathrm{C}$, followed by an increase of $25^{\circ} \mathrm{C} / \mathrm{min}$ to $210^{\circ} \mathrm{C}$ where it stopped for two minutes. Detector temperature was $290^{\circ} \mathrm{C}$. Nitrogen was used as a carrier gas at a flow rate of about $11 \mathrm{ml} / \mathrm{min}$.

\section{CALCULATIONS}

By definition the partition coefficient of a substance is the quotient of the concentration (C) in the two phases at equilibrium:

$\lambda_{\text {liq/air }}=\mathrm{C}_{\text {liq }} / \mathrm{C}_{\text {air }}$

The concentration may be expressed as the amount of substance divided by the volume (V). The gas volume is equal to the total volume minus the volume of the liquid. Assuming no losses, the amount of substances in the liquid phase must equal the amount added minus the amount in the air phase. The amount added is the same in the sample vial as in the reference vial and because there is no partition in the reference vial the amount added is easily measured in the reference vial, since the amount in the gas phase is proportional to the area under the curve (B). Hence, equation 1 may be rewritten as:

$\lambda_{\text {liq/air }}=\left(\left(\mathrm{V}_{\text {tot }}-\mathrm{V}_{\text {liq }}\right) \times\left(\mathbf{B}_{\text {ref }}-B_{\text {air }}\right)\right) /\left(B_{\text {air }} \times V_{\text {liq }}\right)$

Essentially the same method was described by Sato and Nakajima. ${ }^{14}$

The partition coefficient between two liquids is calculated as the quotient of the partition coefficient between one liquid and air and the partition coefficient between the other liquid and air.

To ensure that other terpenes or impurities did not interfere with the analysis and to avoid memory effects, the column temperature was programmed $25^{\circ} \mathrm{C} / \mathrm{min}$ to $220^{\circ} \mathrm{C}$ between analyses. When water, olive oil, or blood were equilibrated and analysed, without any added terpenes, no interfering gas chromatographic peaks were observed. $\alpha$-Pinene and $\beta$-pinene did not interact and were analysed in the same vial. 3-Carene was only $95 \%$ pure and other terpenes were present as impurities. Limonene and 3-carene were analysed separately to avoid interference.

Because of the difficulties in dissolving terpenes in water, dilutions could not be carried out in this medium. Instead the terpenes were injected into a thermostated air chamber with a known volume. A sample was taken out with an air tight syringe and added to a vial. When the sample was added in or above the liquid and the vial was closed directly after the sample was added, losses were observed. To reduce losses, the vial containing the liquid but no terpenes was thermostated and then capped with a Teflon lined rubber stopper. An air volume corresponding to the sampling volume later added to each vial was removed with an air tight syringe. This was done to avoid a higher pressure, when the terpene was added, which would affect the partition coefficient.

\section{Results and discussion}

The standard curves were linear over the whole concentration range $(0.21-89 \mu \mathrm{M}$ for blood and water, $0 \cdot 8-340 \mu \mathrm{M}$ for oil). The retention times and regression equations are given in table 1 . The reproducibility was examined for six samples and the relative standard deviation was found to be $3 \%$.

The experimentally determined partition coefficients between liquid and air increased in the order: $\alpha$-pinene, $\beta$-pinene, 3 -carene, and limonene (table 2). The values were mean values and the concentrations ranged between 21 and $350 \mu \mathrm{M}$ for oil and 0.21 and $89 \mu \mathrm{M}$ for blood and water.

The $\lambda_{\text {water/air }}$ ranged from $0 \cdot 12$ to $1 \cdot 8$ (table 2 ). $\alpha$ Pinene, $\beta$-pinene, and 3-carene were practically insoluble in water and limonene was only slightly soluble.

The high $\lambda_{\text {oil/air }}$ values (2900 to 5700 ) made it difficult to use head space technique to determine the partition coefficient between olive oil and air (table 2 ); the $\lambda_{\text {oil/air }}$ was valid only at higher concentrations (21-350 $\mu \mathrm{M})$.

The $\lambda_{\text {blood/air }}$ values ranged from 15 to 42 (table 2). These values are comparable with those of toluene and styrene which have $\lambda_{\text {blood/air }}$ values of 16 and 52 , respectively. ${ }^{16}{ }^{17}$ The respiratory uptake of toluene is $45 \%$ and of styrene $68 \%$. The high solubility of terpenes in blood suggests a high respiratory uptake of terpenes.

The partition coefficients between tissue and air were estimated from the fractional composition of water and fat in the tissue (table 3). Calculating partition coefficients from tissue composition has the advantage that the coefficients may be predicted for

Table 1 Retention times and regression equation of the standard curves of four terpenes

\begin{tabular}{|c|c|c|c|c|}
\hline Compound & Retention time (min) & Regression equation & $\begin{array}{l}\text { No of } \\
\text { samples }\end{array}$ & $\begin{array}{l}\text { Coefficient of } \\
\text { correlation }\end{array}$ \\
\hline $\begin{array}{l}\alpha \text {-Pinene } \\
\beta \text {-Pinene } \\
\text { 3-Carene } \\
\text { Limonene }\end{array}$ & $\begin{array}{l}2 \cdot 4 \\
3 \cdot 2 \\
3 \cdot 6 \\
4 \cdot 3\end{array}$ & $\begin{array}{l}\ln (\text { peak area })=0.1408+0.8791 \times \ln (\text { conc }) \\
\ln (\text { peak area })=0.0638+0.8276 \times \ln (\text { conc }) \\
\ln (\text { peak area })=-0.2614+0.8968 \times \ln (\text { conc }) \\
\ln (\text { peak area })=-0.0045+0.8214 \times \ln (\text { conc })\end{array}$ & $\begin{array}{l}20 \\
20 \\
20 \\
20\end{array}$ & $\begin{array}{l}0.99 \\
0.95 \\
0.99 \\
0.98\end{array}$ \\
\hline
\end{tabular}


Table 2 Partition coefficients (mean (SD) $(n=20)$ of four terpenes in blood, water, and oil at $37^{\circ} \mathrm{C}$

\begin{tabular}{|c|c|c|c|c|c|}
\hline Compound & $\begin{array}{l}\text { Blood/ } \\
\text { air }\end{array}$ & $\underset{\text { air }}{\text { Water }}$ & Oil/air ${ }^{\star}$ & $\begin{array}{l}\text { Oill } \\
\text { blood } \dagger\end{array}$ & Blood/air $\ddagger$ \\
\hline $\begin{array}{l}\alpha \text {-Pinene } \\
\beta \text {-Pinene } \\
\text { 3-Carene } \\
\text { Limonene }\end{array}$ & $\begin{array}{l}15(4) \\
23(6) \\
32(7) \\
42(8)\end{array}$ & $\begin{array}{l}0.12(0.36) \\
0.12(0.27) \\
0.41(0.58) \\
1.8(1.5)\end{array}$ & $\begin{array}{l}2900(460) \\
4300(720) \\
5000(1200) \\
5700(1400)\end{array}$ & $\begin{array}{l}190 \\
190 \\
160 \\
140\end{array}$ & $\begin{array}{l}17 \\
25 \\
30 \\
36\end{array}$ \\
\hline
\end{tabular}

*Obtained by head space gas chromatography at $37^{\circ} \mathrm{C}$.

+ Calculated as $\lambda_{\text {oil/blood }}=\lambda_{\text {oil/air }} / \lambda_{\text {blood/air }}$.

$\ddagger$ Calculated as $\lambda_{\text {blood/air }}=$ relative content of fat in blood $\times \lambda_{\text {oil/air }}+$ relative content of water in blood $\times \lambda_{\text {water/air }}$.

Table 3 Normal water and fat content in some tissues of adults ( $\%$ of weight of wet tissue) from Fiserova-Bergerova ${ }^{f_{3}}$ and calculated partition coefficients of $\alpha$-pinene from tissue composition

\begin{tabular}{|c|c|c|c|c|}
\hline Tissue & Water & Fat & $\lambda_{\text {Tissuelair }}{ }^{\dagger}$ & $\lambda_{\text {Tissue/blood }} \neq$ \\
\hline $\begin{array}{l}\text { Blood } \\
\text { Brain } \\
\text { Kidney } \\
\text { Liver } \\
\text { Lung } \\
\text { Muscle }\end{array}$ & $\begin{array}{l}79 \\
77 \\
80 \\
79 \\
78 \\
79\end{array}$ & $\begin{array}{c}0.6 \\
11 \\
5.2 \\
5.4 \\
1.7 \\
7.5\end{array}$ & $\begin{array}{r}17 \\
320 \\
150 \\
160 \\
49 \\
220\end{array}$ & $\begin{array}{c}\overline{18} \\
8 \cdot 6 \\
9 \cdot 0 \\
2 \cdot 8 \\
12\end{array}$ \\
\hline
\end{tabular}

*Average of grey and white matter.

†Calculated as $\lambda_{\text {tisue/air }}=$ relative content of fat in tissue $\times \lambda_{\text {oil/air }}+$ relative content of water in tissue $\times \lambda_{\text {water/air }}$

$\ddagger$ Calculated as $\lambda_{\text {tissue/blood }}=\lambda_{\text {rissue/air }} / \lambda_{\text {blood/air }}$.

various tissues from easily obtained information. The estimated $\lambda_{\text {blood/air }}$ was compared with the experimentally determined $\lambda_{\text {blood/air }}($ table 2 ) and there was good correlation between the two. All four terpenes examined in this study had a $\lambda_{\text {oil/blood }}$ between 100 and 200 (table 2) similar to that of styrene, a lipophilic compound, with a $\lambda_{\text {oil/bood }}$ of 105 . The estimated uptake of styrene in adipose tissue was $13 \%$ of the total uptake during short time exposure ${ }^{16}$ which suggests that $10-15 \%$ of the total uptake of terpenes will accumulate in adipose tissue under similar exposure conditions.

We conclude that $\alpha$-pinene, $\beta$-pinene, and 3carene are practically insoluble in water and limonene is slightly soluble. All four terpenes are easily dissolved in oil and blood. The solubility of terpenes in blood and other tissues suggests that their res- piratory uptake is high and that they accumulate in adipose tissues.

Requests for reprints to: Agneta Falk, National Institute of Occupational Health, S-171 84 Solna, Sweden.

1 Grim W, Gries H. Turpentine. In: Parmeggiani L, ed. Encyclopaedia of occupational safety and health. Geneva: International Labour Office, 1983:2229.

2 Hedenstierna G, Alexandersson R, Wimander K, Rosen G. Exposure to terpenes: effects on pulmonary function. Int Arch Occup Environ Health 1983;51:191-8.

3 Lindberg E. Exposure to terpenes. Correlation between exposure and some pulmonary function variables. Arbete och Hälsa 1979;27:1-26. (English abstract.)

4 Sandmeyer EE. Alicyclic hydrocarbons. In: Clayton ED, Clayton FE, eds. Patty's industrial hygiene and toxicology. Vol 2b. 3rd ed. London: John Wiley, 1983:3243-6.

5 Schäfer von $R$, Schäfer W. Die perkutane Resorption verschiedener Terpene-Menthol, Campher, Limonen, Isobornylacetat, $\alpha$-pinen-aus Badezusätzen, Arzneimittelforschung Drug Research 1982;1:56-8.

6 Sperling F, Marcus WL, Collins C. Acute effects of turpentine vapor on rats and mice. Toxicol Appl Pharmacol 1967;10:8-10.

7 Savolainen H, Pfäffli P. Effects of long-term turpentine inhalation on rat brain protein metabolism. Chem Biol Interact 1978:21:271-6.

8 Köppel C, Tenczer J, Tönnesmann U, Schirop T, Ibe K. Acute poisoning with pine oil-metabolism of monoterpenes. Arch Toxicol 1981;49:73-8.

9 Brun R. Epidemiology of contact dermatitis in Geneva (1000 cases). Contact Dermatitis 1975;1:214-7.

10 Dooms-Goossens A, Degreef H, Holvoet C, Maertens $M$. Turpentine-induced hypersensitivity to peppermint oil. Contact Dermatitis 1977;3:304-8.

11 Hedenstierna G, Alexandersson R, Rosen G, Wimander K, Randma E. Symptoms and pulmonary function after exposure to terpenes at work. Arbete och Hälsa 1984;8:1-20. (English abstract.)

12 Fiserova-Bergerova V, Diaz M. Determination and prediction of tissue-gas partition coefficients. Int Arch Occup Environ Health 1986;58:75-87.

13 Fiserova-Bergerova V. Gases and their solubility: a review of fundimentals. In: Fiserova-Bergerova V, ed. Modelling of inhalation exposure to vapors: uptake, distribution and elimination. Vol 1. Boca Raton, Florida: CRC Press, 1983:3-28.

14 Sato A, Nakajima T. Partition coefficients of some aromatic hydrocarbons and ketones in water, blood, and oil. $\mathrm{Br} J$ Ind Med 1979;36:231-4.

15 Gargas ML, Seybold PG, Andersen MA. Modeling the tissue solubilities and metabolic rate constant (Vmax) of halogenated methanes, ethanes and ethylenes. Toxicol Lett 1988;43: 235-56.

16 Wigaeus E, Löf A, Bjurström R, Byfält-Nordqvist M. Exposure to styrene. Uptake, distribution, metabolism and elimination in man. Scand J Work Environ Health 1983;9:479-88.

17 Carlsson A. Exposure to toluene: uptake, distribution and elimination in man. Scand $J$ Work Environ Health 1982;8: 43-55.

Accepted 19 April 1989 